\title{
Regional Climate Variability Responses to Future Land Surface Forcing in the Brazilian Amazon
}

\author{
Tao Zhang, ${ }^{1,2}$ Jinyan Zhan, ${ }^{3}$ Feng $W u,{ }^{3}$ Jiao Luo, ${ }^{3}$ and Juan Huang ${ }^{3}$ \\ ${ }^{1}$ Institute of Geographic Sciences and Natural Resources Research, Chinese Academy of Sciences, Beijing 100101, China \\ ${ }^{2}$ Center for Chinese Agricultural Policy, Chinese Academy of Sciences, Beijing 100101, China \\ ${ }^{3}$ State Key Laboratory of Water Environment Simulation, School of Environment, Beijing Normal University, Beijing 100875, China
}

Correspondence should be addressed to Jinyan Zhan; zhanjy@bnu.edu.cn

Received 6 July 2013; Revised 6 September 2013; Accepted 13 September 2013

Academic Editor: Xiangzheng Deng

Copyright (C) 2013 Tao Zhang et al. This is an open access article distributed under the Creative Commons Attribution License, which permits unrestricted use, distribution, and reproduction in any medium, provided the original work is properly cited.

\begin{abstract}
Tropical deforestation could destabilize regional climate changes. This paper aimed to model the potential climatological variability caused by future forest vulnerability in the Brazilian Amazon over the 21th century. The underlying land surface changes between 2005 and 2100 are first projected based on the respectable output produced by Hurtt et al. Then the weather research and forecasting (WRF) model is applied to assess the impacts of future deforestation on regional climate during 2090-2100. The study results show that the forests in the Brazilian Amazon will primarily be converted into dryland cropland and pasture in the northwest part and into cropland/woodland mosaic in the southeast part, with 5.12\% and $13.11 \%$, respectively. These land surface changes will therefore lead to the significant reduction of the sum of sensible heat flux and latent heat flux and precipitation and the increase of the surface temperature. Furthermore, the variability of surface temperature is observed with close link to the deforested areas.
\end{abstract}

\section{Introduction}

Anthropogenic climate changes have attracted worldwide concerns. The coupling mechanism between land surface vulnerability and hydrological and climatological variability has been increasingly investigated and assessed during the last decades [1-4]. Generally, changing in human dominated land use or natural vegetation covers has affected the climate conditions through biogeophysical and biogeochemical processes, by shifting the surface energy, thermodynamic momentum, moisture budget, and atmospheric components [5-9]. Large-scale land conversions, such as unprecedented urban area expansion $[10,11]$, intensified agricultural activities $[12,13]$, and high tropical and boreal deforestation rate [14], are mainly caused by the human land use practices directly or indirectly, which is to meet the demand of human immediate necessities [15-20]. As a result, these land conversions have had great corresponding repercussions on climate anomalies at different scales, as well as other adverse effects in terms of biodiversity decline, ecosystem degradation, and economic loss [21]. Though most current global climate concerns are focused on the first-order external forcing [22], such as the concentration of carbon dioxide $\left(\mathrm{CO}_{2}\right)$ which primarily originated from the fossil fuels combustion and anthropogenic land use practices, the land surface changes which have influenced or will influence natural climate variability in history, current, and future have fascinated diverse community of scholars [23].

Forests, covering more than $30 \%$ of terrestrial land $[1,24]$, mainly comprise tropical, temperate, and boreal types from which invaluable ecological, socioeconomic, and mental public goods and services are provided for humanity. Furthermore, Forests can also affect multiscale climate by exchanging the planetary energetics, sustaining the hydrologic cycle, containing and releasing the carbon dioxide and through other physical, chemical, and morphological processes [1], which thus play an indispensable role in balancing the humanity, climate, and land surface systems at different temporal and spatial scales through the complicated and nonlinear interactions [25-28].

Among these forest types, tropical forest occupies nearly $20 \%$ of total forest land area and appropriates more than 
$30 \%$ of net primary production (NPP) in the terrestrial ecosystem. This outstanding biomass can sequester a great deal of $\mathrm{CO}_{2}$, maintaining above $25 \%$ on land surface [29], which doubles or triples that of temperate and boreal forests $[1,30,31]$. Well-functioned tropical forest could effectively accelerate the evapotranspiration rate, cool the atmospheric temperature, and increase the rainfall [32]. Some earlier experimental simulations in which the tropical forest was entirely replaced with low coverage vegetation [29, 33-37] suggested that these changes would induce increase in surface temperature, in comparison to the decrease of precipitation, evapotranspiration, soil moisture, and cloud cover caused by the increase of surface albedo and decrease of surface roughness. Though tropical forest could mitigate surface warming through considerable evaporative cooling effect, the temperature would increase if the surface albedo rose to a large extent induced by deforestation which would offset the water and energy exchange feedback effects, compared with the reduction of convection and precipitation [38]. Therefore, no debate of this issue would be complete without taking the tropical forest as a significant component into account in climate change researches.

The Amazonia tropical forest with an area of 6 million $\mathrm{km}^{2}$, nearly $80 \%$ of its original area, covers half of the global remaining tropical forests, and approximatly $60 \%$ is located in the Brazilian Amazon region. The annual average forest clearing rate in Brazil has accelerated in the past 15 years and shown a decrease trend in recent years, from $1.3 \times 10^{4} \mathrm{~km}^{2}$ in 1990-1994 to above $2.0 \times 10^{4} \mathrm{~km}^{2}$ in the next two years, then to $1.9 \times 10^{4} \mathrm{~km}^{2}$ until 2005 and less than $0.7 \times 10^{4} \mathrm{~km}^{2}$ in 2011 [39-41]. The quality of forest has also experienced a significant loss (Table 1). Given the massive ecological services in water maintain and climate regulation, the annual average precipitation in Amazon reaches 2,500 mm, and it can discharge over a trillion $\mathrm{m}^{3}$ of water into the ocean. Without these tropical forest featured by low albedo, great radiative forcing, and high evapotranspiration rate, the local residents should not have had such habitable zones with a cool and wet boundary [42]. Although the tropical forests are an indispensable component of regional ecological system and humanity, anthropogenic activities have caused the shift of climatic states by disturbing and clearing the tropical forest [43]. This land surface change would destabilize regional climatic and hydromeoterological variability $[30,44]$ and then induce the climate anomalies such as changing in precipitation and temperature $[44,45]$.

Numerous researches have been conducted to assess the potential climatological changes of tropical deforestation in (Brazilian) Amazon using the global or regional climate models $[28,46,47]$ and shared a common view that the vast tropical forest plays a pivotal role in changing climatic conditions. But these studies are lacking thorough and profound investigation due to the demerits of numerical models and data availability. As to the global climate models (GCMs), its rough resolution is inappropriate to reveal the land surface-atmosphere interactions for regional simulation cases. Importantly, it is worth pointing out that the entire Amazon forests have been entirely converted into
TABLE 1: The forest area and biomass stock in Brazil from 1990 to 2005. This table shows a dramatic reduction in both forest quantity and quality. The data is obtained from the website of Food and Agriculture Organization of the United Nations, global forest resources assessment, 2005 available online at: http://www.fao.org/forestry/country/32185/en/bra/ and http://www fao.org/forestry/country/32183/en/bra/.

\begin{tabular}{lccc}
\hline Categories & 1990 & 2000 & 2005 \\
\hline Forest area $\left(10^{6}\right.$ hectares $)$ & & & \\
$\quad$ Primary & 460.51 & 433.22 & 415.89 \\
Modified natural & 54.44 & 54.71 & 56.42 \\
$\quad$ Productive plantation & 5.07 & 5.28 & 5.38 \\
$\quad$ Total & $\mathbf{5 2 0 . 0 3}$ & $\mathbf{4 9 3 . 2 1}$ & $\mathbf{4 7 7 . 7 0}$ \\
Biomass stock $\left(10^{3}\right.$ million & & & \\
metric tonnes oven-dry & & & \\
weight) & & & \\
Above ground biomass & 86.09 & 82.68 & 79.22 \\
Below ground biomass & 24.43 & 22.86 & 22.02 \\
Dead wood & 6.88 & 6.56 & 6.36 \\
Total & $\mathbf{1 1 7 . 4 0}$ & $\mathbf{1 1 2 . 1 0}$ & $\mathbf{1 0 7 . 6 0}$ \\
\hline
\end{tabular}

low coverage vegetation in terms of pasture, savanna, and cropland in the GCMs performances. Though this unrealistic replacement assumption could help to understand the importance of tropical deforestation to regional and global climate changes as a whole, it is unable to help revealing the regional anthropogenic climate changes mechanism. In contrast, although the regional climate models (RCMs) with higher resolution are better at revealing the mesoscale effects of land surface changes on regional climate variability, the potential climate uncertainties induced by future land surface modification and vegetation alteration are still far from known.

Thus, the scientific objective of this paper is to estimate the potential impacts of future tropical deforestation on regional climate changes in Brazilian Amazon during 20902100 , with the performance of a high resolution numerical model-weather research and forecasting (WRF) model. For this purpose, a relative rational underlying land surface with high resolution should be projected first. Given the observations and investigations which showed that remarkable progress in curbing tropical forests recession has been made in recent years as previously mentioned, the prevailing unreasonable land surface scenarios in which the entire forests were replaced with low coverage vegetation would not be used in this paper. We analyzed the characteristics of forest land transformation between 2005 and 2100, and then the land surface map in particular years could be identified. Thereafter, the control and simulation experiments are designed for WRF performance.

\section{Data and Methodology}

2.1. Data. The data used in this paper include land surface data and lateral forcing conditions. The respectable land cover product, generated by the GCAM model under 
the implementation of the state-of-the-art Representative Concentration Pathway scenarios (RCPs), is used to analyze the characteristics of land cover conversions, such as the changing trend and the fraction, which is critical to project the future land surface properties $[48,49]$. These data harmonized the historical land uses and the future land surface scenarios for studying the anthropogenic impacts and the annually fractional landscape patterns and land surface transitions for the period $1500-2100$ at $0.5^{\circ} \times 0.5^{\circ}$ resolutions. For the purpose of this study, the forest land conversions during the period from 2005 to 2100 will be identified.

There are three steps to predict and generate the future land surface map. Firstly, the fraction of transitioned cell that converted from the primary forest and the secondary forest into other land cover types, including cropland, pasture, and built-up land, was calculated to capture the changing characteristics at temporal and spatial scales between 2005 and 2100. Then the transformation thresholds were set to identify the targeted grid cells with vast changed area. The fraction thresholds of grid cells that converted from forest land to dryland cropland and pasture (pasture) and cropland/woodland mosaic (woodland) were 0.15 and 0.02 , respectively. The grid cell would be considered converting from forest to pasture if both thresholds were reached. Finally, label and replace the initial land surface map in 2005, which is processed with USGS land cover classification at the resolution of $30 \mathrm{~km} \times 30 \mathrm{~km}$ and will be used in the control experiment, with corresponding targeted land cover types. By doing this, a relative reasonable future land surface in 2100 is generated as compared with that of most researches in which replacing the entire tropical forest with cropland or savanna vegetation types [45]. Thereafter, a rectangle region was selected as the study area covering the changed grid cells as many as possible (Figure 1). High resolution with this grid size can also help to reveal the land-atmosphere interactions as well as the cumulus parameterization and weather.

The lateral boundary forcing data is created by and obtained from the Centre for Environmental Prediction (NECP) and covered 6 hours temporally, with the spatial resolution of $1^{\circ} \times 1^{\circ}$ (longitude $\times$ latitude) and the vertical resolution of 27 pressure layers. As mentioned above, the USGS land use and land cover system is used to determine the topography information and land surface physical properties. The buffer zone of the lateral boundary is set to 4 layers of grid points. The WRF model integrates at a 5-minute step, as well as the cumulus convection processes operation, but run the radiation process at a 0.5 hour step.

2.2. WRF Model and Experiments. The Advanced Research WRF model (ARW-WRF, version 3.3) is used in this study. Created by key institutions involving National Center for Atmospheric Research (NCAR), Air Force Weather Agency (AFWA), National Oceanic and Atmospheric Administration (NOAA), ARW-WRF model is a fully compressed nonhydrostatic equation model, including the prognostic variables referred to wind, perturbation, and other scalars, and it is possible to mix the dynamic cores and model physics packages [50,51]. To assess the model performance,
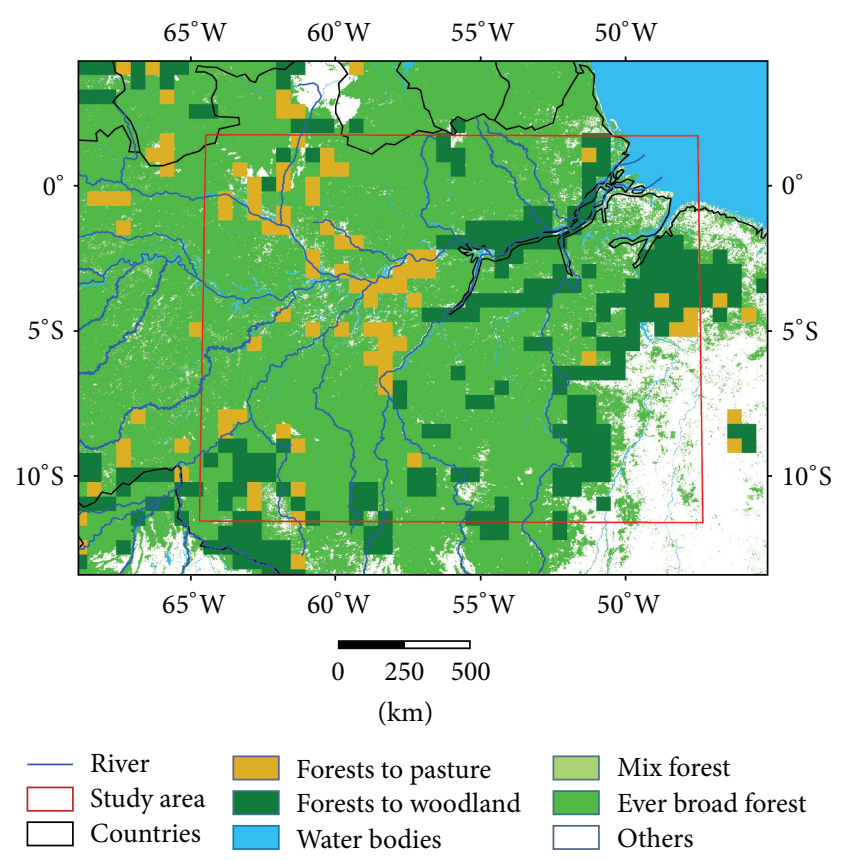

FIgURE 1: The land surface properties in Brazilian Amazon. Only forests and water bodies are shown in the land cover layer $(1 \mathrm{~km} \times$ $1 \mathrm{~km}$, USGS land cover classification). Grid cells in which forests are converted into the pasture (yellow) and woodland (darkgreen) are provided in the land surface change layer $\left(0.5^{\circ} \times 0.5^{\circ}\right)$. The study area (red rectangle) covers most changed forest land cells.

the land cover data and meteorology data in 2010 are used to validate and calibrate the model parameterization. The results illustrated the ability of WRF model to evaluate the impacts of land surface changes on climate variability. Since the study area was selected, the WRF model is set up with a grid of $63 \times 49$ cells, and each one representing a $30 \mathrm{~km} \times 30 \mathrm{~km}$ area, centered at $5^{\circ} \mathrm{S}, 56^{\circ} \mathrm{W}$.

For assessing the impacts of deforestation on climate, other variables were controlled but to modify the land surface map and relative properties in the model scheme. To achieve this goal, two experiments were designed, including the control experiment and simulation experiment. In the control experiment, which is regarded as the reference case, the current land surface map in 2005 is used as the basic land cover data, maintaining constant in the whole simulation process. By contrast, the simulation experiment is designed with the implementation of project land surface map in 2100 in which certain numbers of grid cells are converted from the forests into dryland cropland and pasture (pasture) and cropland/woodland mosaic (woodland) (Figure 1). This replacement will result in changing of corresponding biogeophysical parameters such as root depth, canopy height, and other variables in the WRF model. The climatic metrics in terms of sensible heat flux, latent heat flux, precipitation, and temperature in two experiments are simulated and processed into annual domain-averaged variables during the simulation period of 2090-2100, and the differences of each climate metric between two experiments are also modeled. 


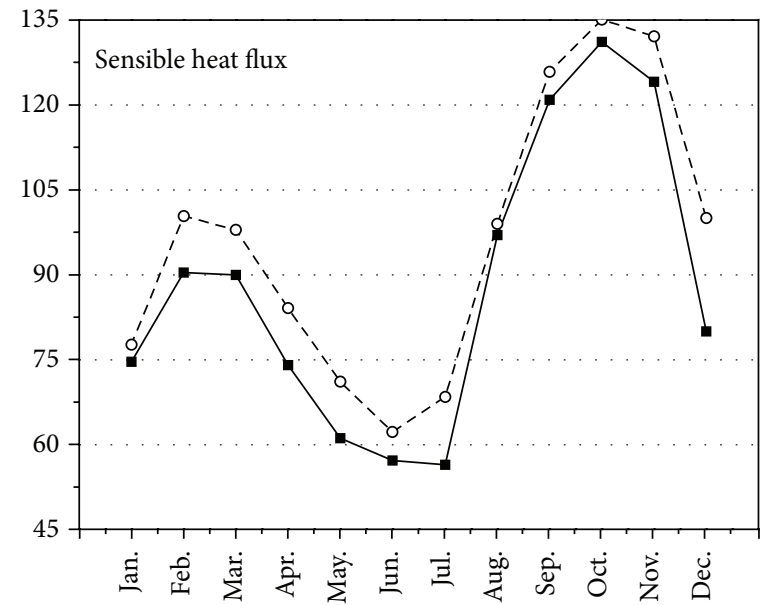

(a)

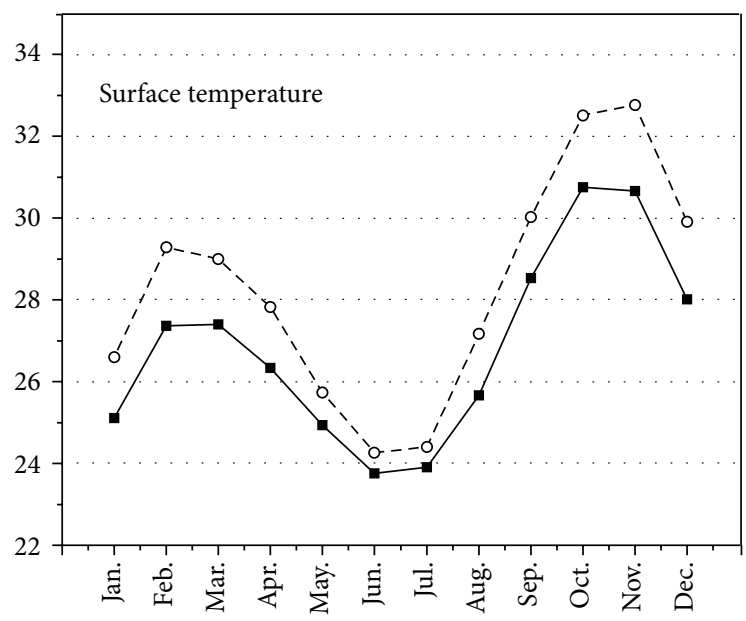

(c)

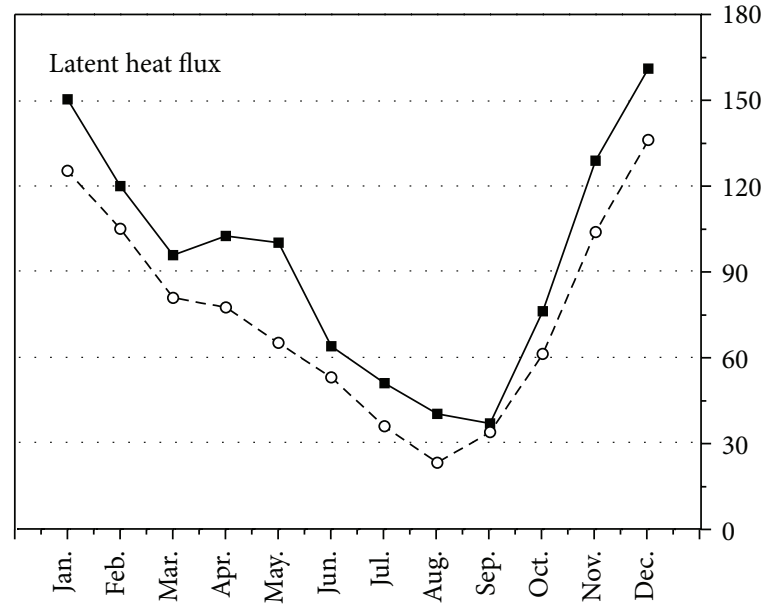

(b)

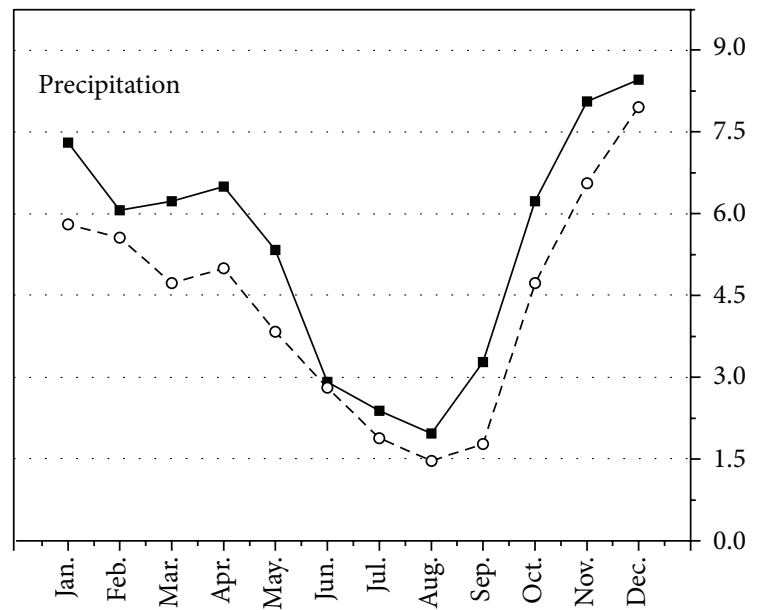

(d)

Figure 2: Annual cycles' domain-averaged in the years $2090-2100$ between $49^{\circ} \mathrm{W}$ and $63^{\circ} \mathrm{W}$ and $12^{\circ} \mathrm{S}$ and $2^{\circ} \mathrm{N}$. All flux is in W/m ${ }^{2}$, surface temperature in ${ }^{\circ} \mathrm{C}$, precipitation in $\mathrm{mm}$. Solid line is the control simulation, and the dashed line is deforestation simulation.

\section{Results and Discussion}

3.1. Future Land Surface Properties. In the Brazilian Amazon, the entire forest accounts for $78.07 \%$ of the total area in the year 2005, totally contributed by the evergreen broadleaf forest. According to the statistical analysis, the projected deforested land occupies $18.23 \%$ of the study area during the period from 2005 to 2100 . The ratios of cells in which forest is converted into pasture and woodland to the total grid cells in the study area are $5.12 \%$ and $13.11 \%$, respectively at the same time. Specifically, the primary forest degrades by $13.36 \%$ of the study area, among which $32.04 \%$ is converted into the pasture and $67.96 \%$ is transitioned into the woodland. The secondary forest decreases by $4.33 \%$ in the study area, among which $19.40 \%$ is transitioned from forest into pasture and $80.60 \%$ into the woodland. Furthermore, the proportion of each cell in which primary forest is converted to pasture and woodland ranges from 0 to $56.51 \%$ and from 0 to $20.70 \%$, respectively, from 2005 to 2100, in comparison to those of the secondary forest ranges from 0 to $37.70 \%$ and from 0 to $15.31 \%$, respectively. In this study, by considering the potential joint efforts to curb the deforestation in the future that may result in reaching the saturation point of forest clearing rate, we then set quite lower thresholds than current deforestation rate $(0.7 \%)$. Therefore, the conversion thresholds would have had influences on the future land surface projection.

Figure 1 provides the geographical distribution of changed forest land. The degraded and transitioned grid cells are primarily distributed in the periphery of the entire Amazon, or along the rivers. Particularly, most grid cells in which forests are converted into pasture are mainly located in the northwest part of the study area, where containing a great deal of water resource supplied by the dense water network. By contrast, the cells in which forest is converted into cropland are principally distributed in the most disturbed and populated area, especially the transition zones between forests and other land cover types.

3.2. Heat Fluxes. The yearly averaged sum of sensible and latent heat flux serves as an indicator for estimating the energy exchange between land surface and atmosphere 


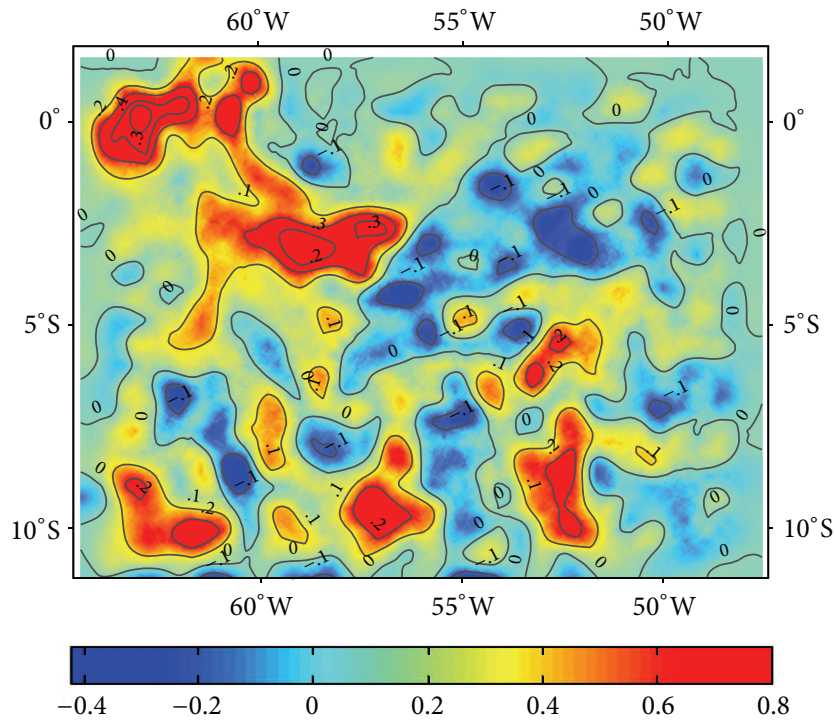

(a)

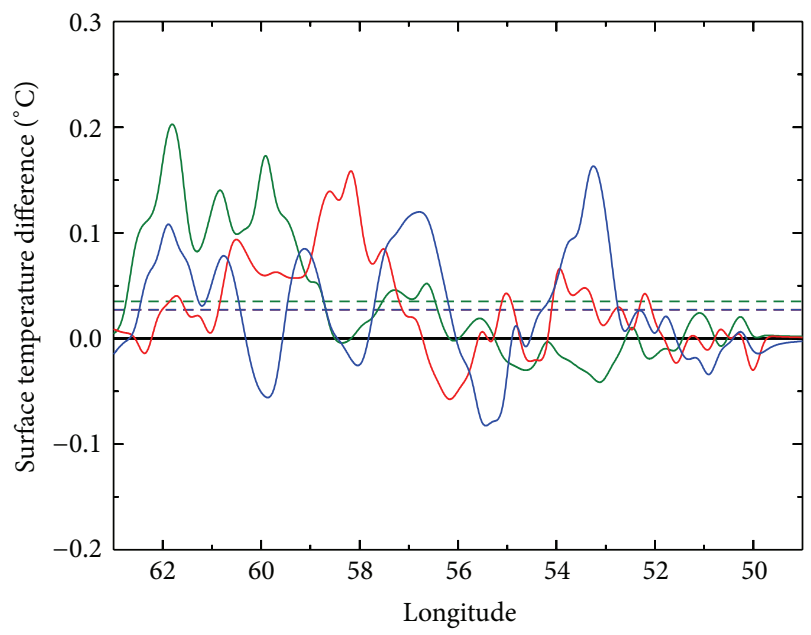

North, $2^{\circ} \mathrm{N}-2^{\circ} \mathrm{S}$

- South, $8^{\circ} \mathrm{S}-12^{\circ} \mathrm{S}$

(c)

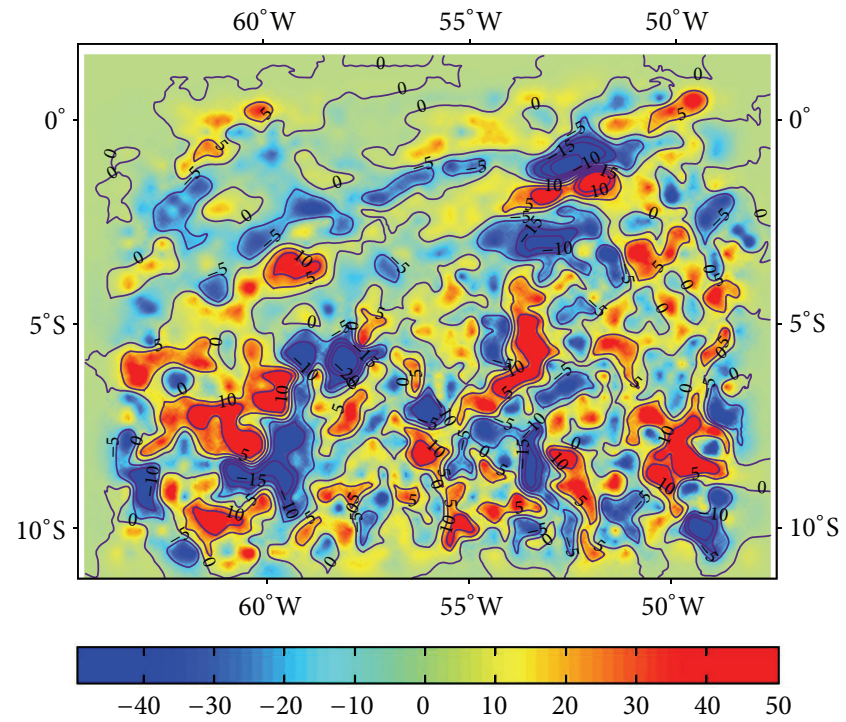

(b)

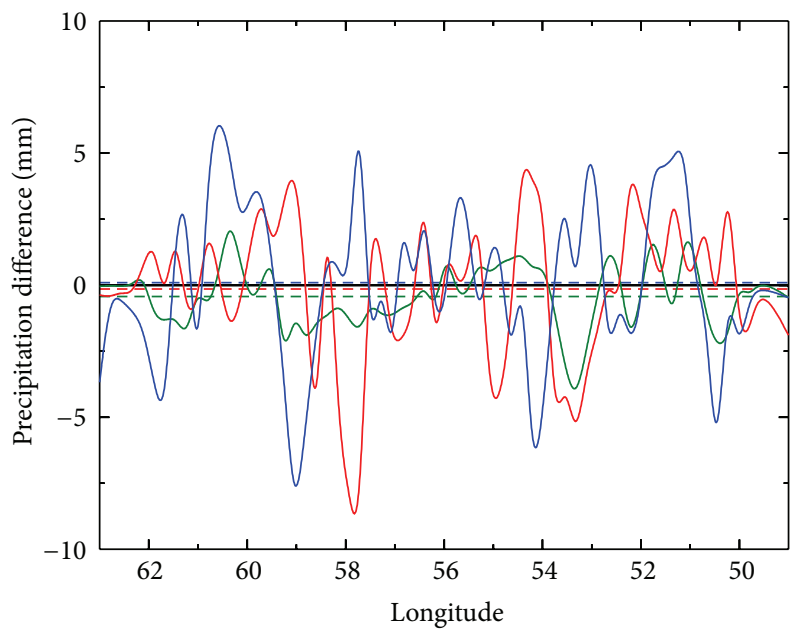

North, $2^{\circ} \mathrm{N}-2^{\circ} \mathrm{S}$

- South, $8^{\circ} \mathrm{S}-12^{\circ} \mathrm{S}$

(d)

Figure 3: (a) and (b) show the yearly-averaged deviations of surface temperature (a) and precipitation (b) in the year 2100 (deforestation minus control). The surface temperature is contoured at a $0.1^{\circ} \mathrm{C}$ interval, and the precipitation is contoured at a $5 \mathrm{~mm}$ interval. (c) and (d) are zonally averaged surface temperature (c) and precipitation (d) differences (deforestation minus control). Green line indicates the north region between $2^{\circ} \mathrm{N}$ and $2^{\circ} \mathrm{S}$ of the Brazilian Amazon, red line is the central region between $2^{\circ} \mathrm{S}$ and $8^{\circ} \mathrm{S}$, blue line is the south region between $8^{\circ} \mathrm{S}$ and $12^{\circ} \mathrm{S}$, and the dash lines are averages of zonally surface temperature and precipitation.

during 2090-2100. Generally, based on the model analysis, deforestation will cause a reduction in surface heat flux with approximate $5 \mathrm{~W} / \mathrm{m}^{2}$ per month (Figure 2). In the control simulation, the flux in the east is greater than that in the west, but the eastern area will see a decline in the deforestation simulation. This progressively decrease in the total heat flux illustrates the importance of increase in surface albedo and radiation caused by deforestation. As a result, the annual average sensible heat flux will increase to some extent, especially in the west region covering most changed areas that transited from forest to pasture, while the latent heat flux shows a significant downward trend during the period of 2090-2100. Such spatial gradient of flux will increase the convection by generating a thermally driven circulation, leading to rising of the sensible heat flux over the west part and falling over the east part which will redistribute the temperatures.

3.3. Precipitation and Temperature. On the whole, the annual domain-averaged precipitation will decrease while the temperature will increase during the simulation period. Deforestation in Brazilian Amazon will induce a monthly reduction 


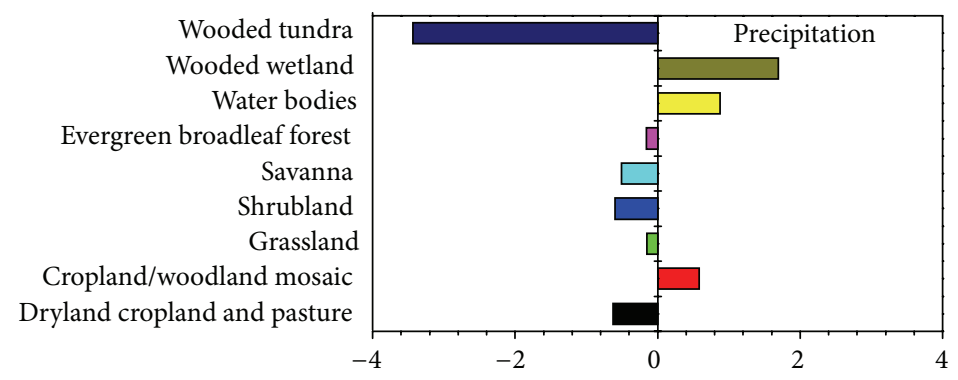

(a)

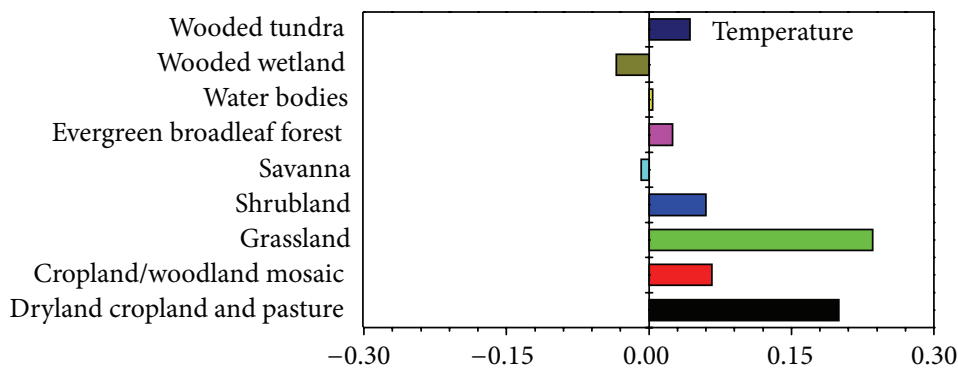

(b)

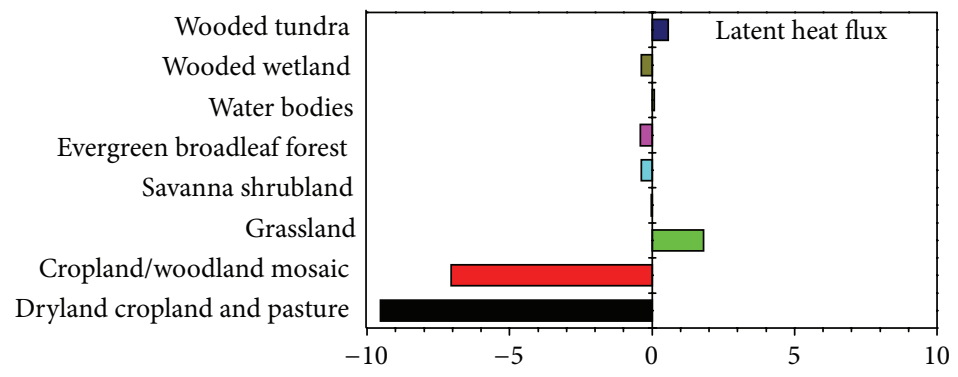

(c)

FIGURE 4: The zonally averaged difference of precipitation $(\mathrm{mm})$, temperature $\left({ }^{\circ} \mathrm{C}\right)$, and latent heat flux $\left(\mathrm{W} / \mathrm{m}^{2}\right)$ of different land covers in Brazilian Amazon in 2100.

in precipitation $(1.05 \mathrm{~mm})$ and a monthly increase in surface temperature $\left(0.12^{\circ} \mathrm{C}\right)$. Figure 2 also shows that the deforestation will cause a significant precipitation reduction in rainy season, but a slight decrease in dry season. Correspondingly, the surface temperature nearly increases to a large extent in rainy season and moderately goes up to a higher level in dry season.

The spatial distribution of differences in surface temperature and precipitation between the control experiment and simulation experiment in 2100 is significantly influenced by the forest land changes. Obviously, the surface temperature increases over the western region, associated with the reduction of precipitation and soil moisture that will reduce the latent heat flux discharge from the land surface into atmosphere. Massive deforested areas experience a significant increase of temperature and decrease of precipitation. However, the spatial distribution of precipitation deviation is not so related to the deforested areas but fragmented in the whole study area. In addition, as can be seen in Figure 3, deforestation will intensify the precipitation shift by increasing its amount in the southeast region even further and decreasing in the northwest region. The precipitation variability can be explained by that deforestation may influence the propagation of squall lines, which will reduce the water supply in these regions. Meanwhile, the convection and speed effects will also impose a negative feedback in these regions.

To study the spatial heterogeneity of these climatic metrics in longitude and latitude direction, the average surface temperature and precipitation in different zones were calculated (Figures 3(c) and 3(d)). Apparently, the surface temperature fluctuates dramatically in the western region and almost remains stable in the eastern part, which means that the surface temperature has a longitudinal distribution characteristic. Meanwhile, the zonally average temperature of north region increases most greatly by $0.0350^{\circ} \mathrm{C}$ in year 2100 induced by deforestation, while that of central region has a less increment of $0.0272^{\circ} \mathrm{C}$, as compared to that of south region with a similar growth by $0.0274^{\circ} \mathrm{C}$. For the precipitation, those of the central region and the southern region fluctuate more strongly than that of the northern region. The zonally annual average precipitation in northern 
region and central region will decrease by $0.433 \mathrm{~mm}$ and $0.147 \mathrm{~mm}$, respectively, while it will slightly increase by $0.09 \mathrm{~mm}$ in the south region.

Variability of climate is also calculated on each land cover type according to the model results in 2100 with the resolution of $30 \mathrm{~km} \times 30 \mathrm{~km}$ (Figure 4). The statistical analysis shows that the average precipitation and latent heat flux of evergreen broadleaf forest will experience a decrease of $0.15 \mathrm{~mm}$ and $0.40 \mathrm{~W} / \mathrm{m}^{2}$, respectively, while the temperature will increase by $0.02^{\circ} \mathrm{C}$. Since forests are converted into pasture and woodland, the corresponding climatic conditions in pasture will have a significant reduction of precipitation and latent heat flux and increase of surface temperature. Unexpectedly, though the latent heat flux of cropland will drop at a significant level, the precipitation will grow to some extent, as well as the temperature. This can be explained by that the flux and wind speed gradient will accelerate the convection and telecommunication in the study area, which will offset the negative effects of hydrometeorological anomalies. Thus, the land cover structure, which means the area and continuity of each land cover type, will also rouse uncertainties to regional climate changes.

\section{Conclusions}

Anthropogenic tropical forests changes have affected and will still affect the regional and global climate. Though plenty of studies have been conducted to explore the influences of vegetation vulnerability on climate variability in Amazon using various methods such as statistical extrapolation and numerical simulation models, no debate of reasonable future tropical forest land changes will be complete without taking the Brazilian Amazonia forests as a key component into account in climate researches with high resolution.

In this paper, the WRF model is used to model the effects of future tropical deforestation on regional climate between 2090 and 2100 in Brazilian Amazon. High resolution land surface map $(30 \mathrm{~km} \times 30 \mathrm{~km})$ with USGS land use and land cover classification, projected from the respectable land surface product that is generated under the state-of-the-art RCP scenarios, is also utilized in this model. Land surface changes are quite different from previous studies. Forests are mainly converted into pasture and woodland, distributed along the edge of the study area and river branches. The simulated climatic results caused by these potential future land surface changes show that expanding deforestation will principally trigger the reduction of precipitation and increase of surface temperature in the deforested area. The sum of sensible heat flux and latent heat flux tends to show a decline at the same period.

However, only the impacts of deforestation on climate are evaluated in this study. In fact, various intangible factors will impose a synthetic effect on regional and global biogeophysical and biogeochemical processes which will influence the hydrological cycle and energy budget, and further result in the climate changes. Thus, the sensitivity analysis on other factors should be required in further studies.

\section{Acknowledgments}

This research was financially supported by the National Key Programme for Developing Basic Science in China (Grant no. 2010CB950900 and Grant no. 2012CB955700). Model development and data support from the Key Project funded by the Chinese Academy of Sciences (no. KZZD-EW-08) and China National Natural Science Funds for Distinguished Young Scholar (Grant no. 71225005) are also appreciated.

\section{References}

[1] G. B. Bonan, "Forests and climate change: forcings, feedbacks, and the climate benefits of forests," Science, vol. 320, no. 5882, pp. 1444-1449, 2008.

[2] R. A. Pielke Sr., "Land use and climate change," Science, vol. 310, no. 5754, pp. 1625-1626, 2005.

[3] K. Hibbard, A. Janetos, D. P. van Vuuren et al., "Research priorities in land use and land-cover change for the Earth system and integrated assessment modelling," International Journal of Climatology, vol. 30, no. 13, pp. 2118-2128, 2010.

[4] X. Deng, C. Zhao, and H. Yan, "Systematic modeling of impacts of land use and land cover changes on regional climate: a review," Advances in Meteorology, vol. 2013, Article ID 317678, 11 pages, 2013.

[5] J. J. Feddema, K. W. Oleson, G. B. Bonan et al., "Atmospheric science: the importance of land-cover change in simulating future climates," Science, vol. 310, no. 5754, pp. 1674-1678, 2005.

[6] H. Salmun and A. Molod, "Progress in modeling the impact of land cover change on the global climate," Progress in Physical Geography, vol. 30, no. 6, pp. 737-749, 2006.

[7] P. A. Dirmeyer, D. Niyogi, N. de Noblet-Ducoudré, R. E. Dickinson, and P. K. Snyder, "Impacts of land use change on climate," International Journal of Climatology, vol. 30, no. 13, pp. 1905-1907, 2010.

[8] J. Jin, S. Lu, S. Li, and N. L. Miller, "Impact of land use change on the local climate over the Tibetan Plateau," Advances in Meteorology, vol. 2010, Article ID 837480, 6 pages, 2010.

[9] S. M. Sterling, A. Ducharne, and J. Polcher, "The impact of global land-cover change on the terrestrial water cycle," Nature Climate Change, vol. 3, no. 4, pp. 385-390, 2013.

[10] J. Li, X. Deng, and K. C. Seto, "Multi-level modeling of urban expansion and cultivated land conversion for urban hotspot counties in China," Landscape and Urban Planning, vol. 108, no. 2-4, pp. 131-139, 2012.

[11] X. Deng, J. Huang, S. Rozelle, and E. Uchida, "Growth, population and industrialization, and urban land expansion of China," Journal of Urban Economics, vol. 63, no. 1, pp. 96-115, 2008.

[12] J. Li, X. Deng, and K. C. Seto, "The impact of urban expansion on agricultural land use intensity in China," Land Use Policy, vol. 35, pp. 33-39, 2013.

[13] Q. Jiang, X. Deng, H. Yan, D. Liu, and R. Qu, "Identification of food security in the mountainous guyuan prefecture of China by exploring changes of food production," Journal of Food, Agriculture and Environment, vol. 10, no. 1, pp. 210-216, 2012.

[14] X. Deng, J. Huang, E. Uchida, S. Rozelle, and J. Gibson, "Pressure cookers or pressure valves: do roads lead to deforestation in China?" Journal of Environmental Economics and Management, vol. 61, no. 1, pp. 79-94, 2011.

[15] J. A. Foley, R. Defries, G. P. Asner et al., "Global consequences of land use," Science, vol. 309, no. 5734, pp. 570-574, 2005. 
[16] J. O. Adegoke, R. Pielke Sr., and A. M. Carleton, “Observational and modeling studies of the impacts of agriculture-related land use change on planetary boundary layer processes in the central U.S.", Agricultural and Forest Meteorology, vol. 142, no. 2-4, pp. 203-215, 2007.

[17] G. P. Asner, A. J. Elmore, L. P. Olander, R. E. Martin, and T. Harris, "Grazing systems, ecosystem responses, and global change," Annual Review of Environment and Resources, vol. 29, pp. 261-299, 2004.

[18] J. Jin and L. Wen, "Evaluation of snowmelt simulation in the Weather Research and Forecasting model," Journal of Geophysical Research: Atmospheres, vol. 117, no. D10, 2012.

[19] M. J. Puma and B. I. Cook, "Effects of irrigation on global climate during the 20th century," Journal of Geophysical Research: Atmospheres, vol. 115, no. D16, 2010.

[20] M. Wang, X. Zhang, and X. Yan, "Modeling the climatic effects of urbanization in the Beijing-Tianjin-Hebei metropolitan area," Theoretical and Applied Climatology, vol. 113, no. 3-4, pp. 377-385, 2013.

[21] X. Deng, J. Huang, F. Qiao et al., "Impacts of El NinoSouthern Oscillation events on China's rice production," Journal of Geographical Sciences, vol. 20, no. 1, pp. 3-16, 2010.

[22] J. Pongratz, C. H. Reick, T. Raddatz, and M. Claussen, "Effects of anthropogenic land cover change on the carbon cycle of the last millennium," Global Biogeochemical Cycles, vol. 23, no. 4, 2009.

[23] J. Y. Liu and X. Z. Deng, "Progress of the research methodologies on the temporal and spatial process of LUCC," Chinese Science Bulletin, vol. 55, no. 14, pp. 1354-1362, 2010.

[24] X. Deng, Q. Jiang, J. Zhan, S. He, and Y. Lin, "Simulation on the dynamics of forest area changes in Northeast China," Journal of Geographical Sciences, vol. 20, no. 4, pp. 495-509, 2010.

[25] E. L. Davin and N. de Noblet-Ducoudré, "Climatic impact of global-scale deforestation: radiative versus nonradiative processes," Journal of Climate, vol. 23, no. 1, pp. 97-112, 2010.

[26] S. Bathiany, M. Claussen, V. Brovkin, T. Raddatz, and V. Gayler, "Combined biogeophysical and biogeochemical effects of largescale forest cover changes in the MPI earth system model," Biogeosciences, vol. 7, no. 5, pp. 1383-1399, 2010.

[27] J. T. Randerson, H. Liu, M. G. Flanner et al., "The impact of boreal forest fire on climate warming," Science, vol. 314, no. 5802, pp. 1130-1132, 2006.

[28] C. A. Nobre, P. J. Sellers, and J. Shukla, "Amazonian deforestation and regional climate change," Journal of Climate, vol. 4, no. 10, pp. 957-988, 1991.

[29] G. B. Bonan, "Effects of land use on the climate of the United States," Climatic Change, vol. 37, no. 3, pp. 449-486, 1997.

[30] Y. Malhi, J. T. Roberts, R. A. Betts, T. J. Killeen, W. Li, and C. A. Nobre, "Climate change, deforestation, and the fate of the Amazon," Science, vol. 319, no. 5860, pp. 169-172, 2008.

[31] K. L. Findell, T. R. Knutson, and P. C. D. Milly, "Weak simulated extratropical responses to complete tropical deforestation," Journal of Climate, vol. 19, no. 12, pp. 2835-2850, 2006.

[32] R. Avissar and D. Werth, "Global hydroclimatological teleconnections resulting from tropical deforestation," Journal of Hydrometeorology, vol. 6, no. 2, pp. 134-145, 2005.

[33] J. H. C. Gash and W. J. Shuttleworth, "Tropical deforestation: albedo and the surface-energy balance," Climatic Change, vol. 19, no. 1-2, pp. 123-133, 1991.

[34] J. Shukla, C. Nobre, and P. Sellers, "Amazon deforestation and climate change," Science, vol. 247, no. 4948, pp. 1322-1325, 1990.
[35] P. K. Snyder, J. A. Foley, M. H. Hitchman, and C. Delire, "Analyzing the effects of complete tropical forest removal on the regional climate using a detailed three-dimensional energy budget: an application to Africa," Journal of Geophysical Research: Atmospheres, vol. 109, no. D21, 2004.

[36] A. J. Negri, R. F. Adler, L. Xu, and J. Surratt, "The impact of Amazonian deforestation on dry season rainfall," Journal of Climate, vol. 17, no. 6, pp. 1306-1319, 2004.

[37] R. Avissar, P. L. Silva Dias, M. A. Silva Dias, and C. Nobre, "The large-scale biosphere-atmosphere experiment in Amazonia (LBA): insights and future research needs," Journal of Geophysical Research: Atmospheres, vol. 107, no. D20, pp. 54-154-6, 2002.

[38] O. L. Phillips, L. E. Aragão, S. L. Lewis et al., "Drought sensitivity of the Amazon rainforest," Science, vol. 323, no. 5919, pp. 13441347, 2009.

[39] W. F. Laurance, "A crisis in the making: responses of Amazonian forests to land use and climate change," Trends in Ecology and Evolution, vol. 13, no. 10, pp. 411-415, 1998.

[40] A. E. Duchelle, M. Cromberg, M. F. Gebara et al., "Linking forest tenure reform, environmental compliance, and incentives: lessons from REDD+ initiatives in the Brazilian Amazon," World Development, 2013.

[41] E. A. Davidson, A. C. de Araüjo, P. Artaxo et al., "The Amazon basin in transition," Nature, vol. 481, no. 7381, pp. 321-328, 2012.

[42] D. Werth and R. Avissar, "The local and global effects of Amazon deforestation," Journal of Geophysical Research: Atmospheres, vol. 107, no. D20, pp. 55-1-55-8, 2002.

[43] R. R. da Silva, D. Werth, and R. Avissar, "Regional impacts of future land-cover changes on the Amazon basin wet-season climate," Journal of Climate, vol. 21, no. 6, pp. 1153-1170, 2008.

[44] S. Baidya Roy and R. Avissar, "Impact of land use/land cover change on regional hydrometeorology in Amazonia," Journal of Geophysical Research: Atmospheres, vol. 107, no. D20, pp. 4-1-412, 2002.

[45] N. Schneider, W. Eugster, and B. Schichler, "The impact of historical land-use changes on the near-surface atmospheric conditions on the Swiss Plateau," Earth Interactions, vol. 8, no. 12, pp. 1-27, 2004.

[46] Y. Ke, L. R. Leung, M. Huang, A. M. Coleman, H. Li, and M. S. Wigmosta, "Development of high resolution land surface parameters for the Community Land Model," Geoscientific Model Development, vol. 5, no. 6, pp. 1341-1362, 2012.

[47] A. Henderson-Sellers, R. E. Dickinson, T. B. Durbidge, P. J. Kennedy, K. McGuffie, and A. J. Pitman, "Tropical deforestation: modeling local- to regional-scale climate change," Journal of Geophysical Research: Atmospheres, vol. 98, no. D4, pp. 72897315, 1993.

[48] G. C. Hurtt, S. Frolking, M. G. Fearon et al., "The underpinnings of land-use history: three centuries of global gridded landuse transitions, wood-harvest activity, and resulting secondary lands," Global Change Biology, vol. 12, no. 7, pp. 1208-1229, 2006.

[49] G. C. Hurtt, L. P. Chini, S. Frolking et al., "Harmonization of land-use scenarios for the period 1500-2100: 600 years of global gridded annual land-use transitions, wood harvest, and resulting secondary lands," Climatic Change, vol. 109, no. 1, pp. 117-161, 2011.

[50] J. Xu and A. M. Powell Jr., "Dynamical downscaling precipitation over Southwest Asia: impacts of radiance data assimilation on the forecasts of the WRF-ARW model," Atmospheric Research, vol. 111, pp. 90-103, 2012. 
[51] M. A. Hernández-Ceballos, J. A. Adame, J. P. Bolívar, and B. A. de la Morena, "A mesoscale simulation of coastal circulation in the Guadalquivir valley (southwestern Iberian Peninsula) using the WRF-ARW model," Atmospheric Research, vol. 124, pp. 1-20, 2013. 

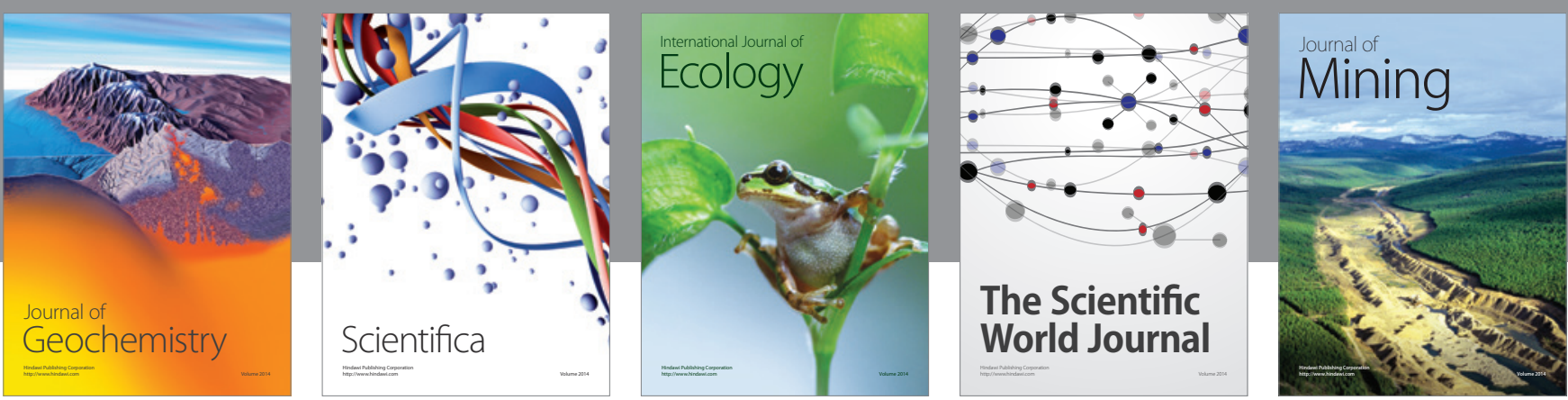

The Scientific World Journal
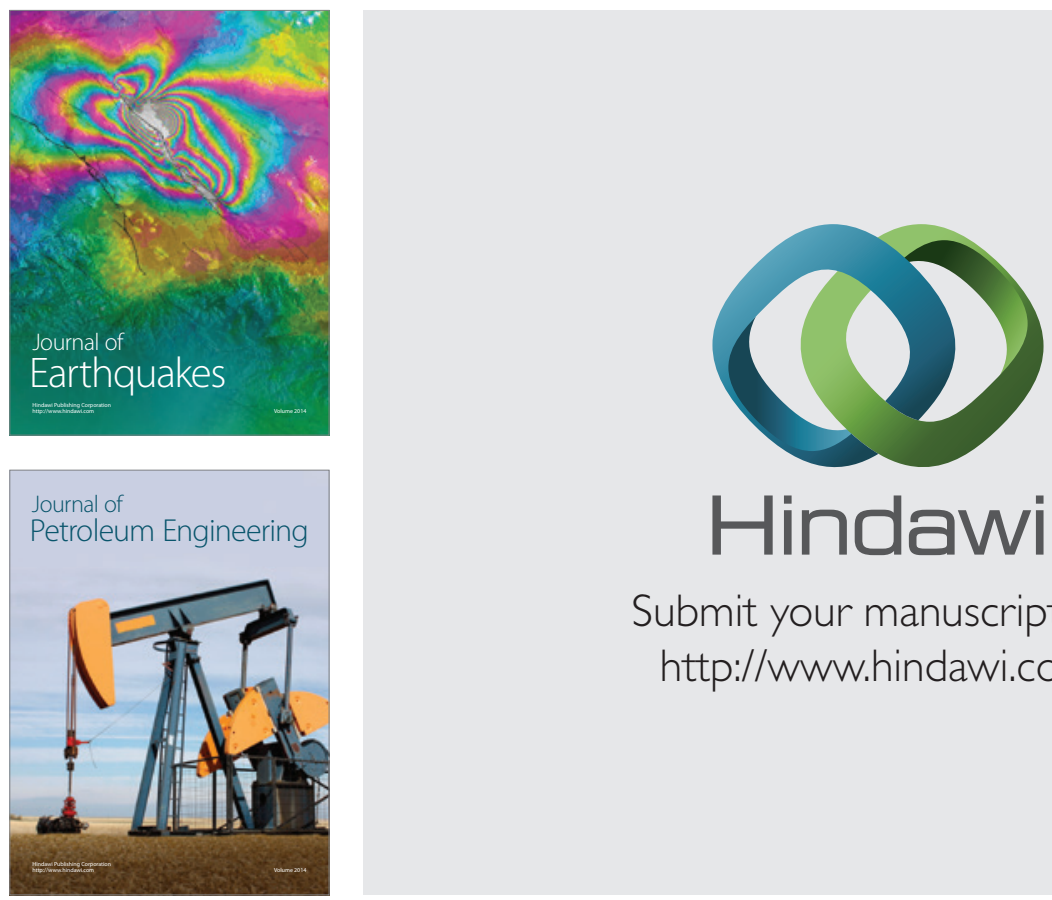

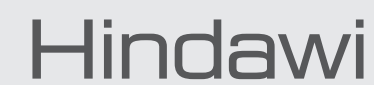

Submit your manuscripts at

http://www.hindawi.com
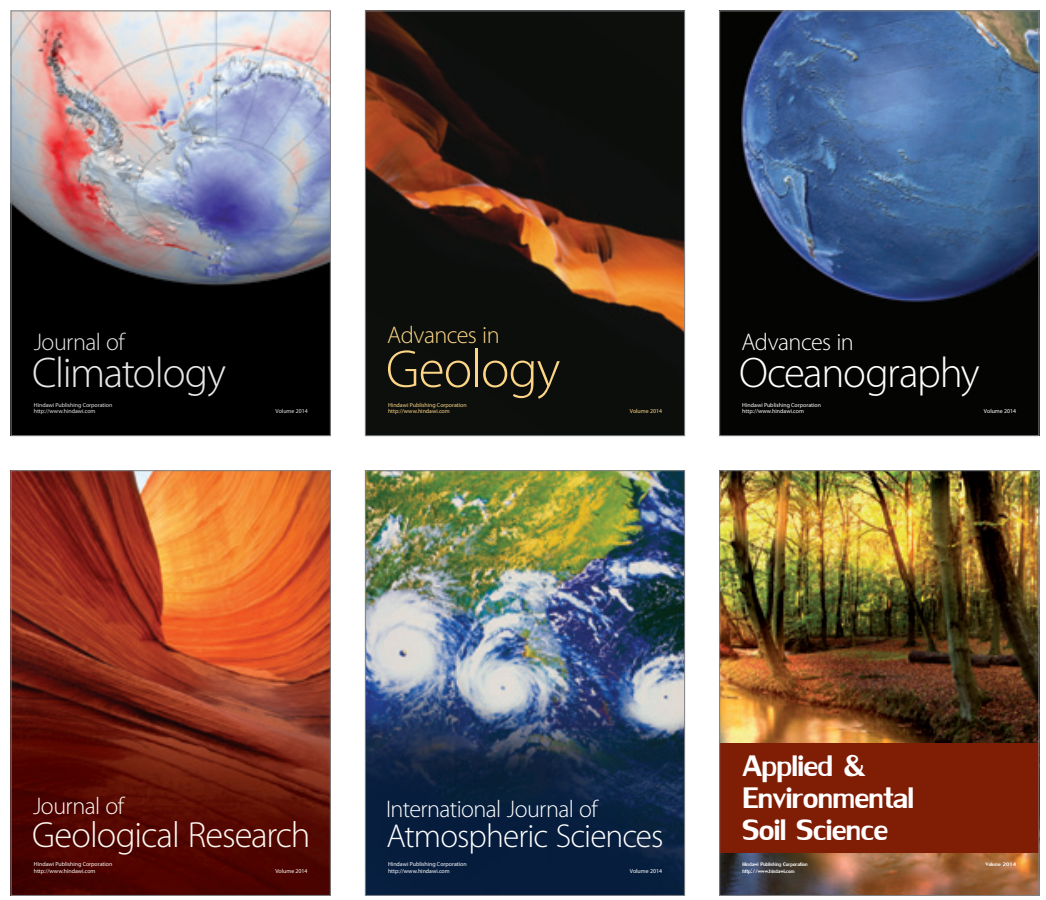
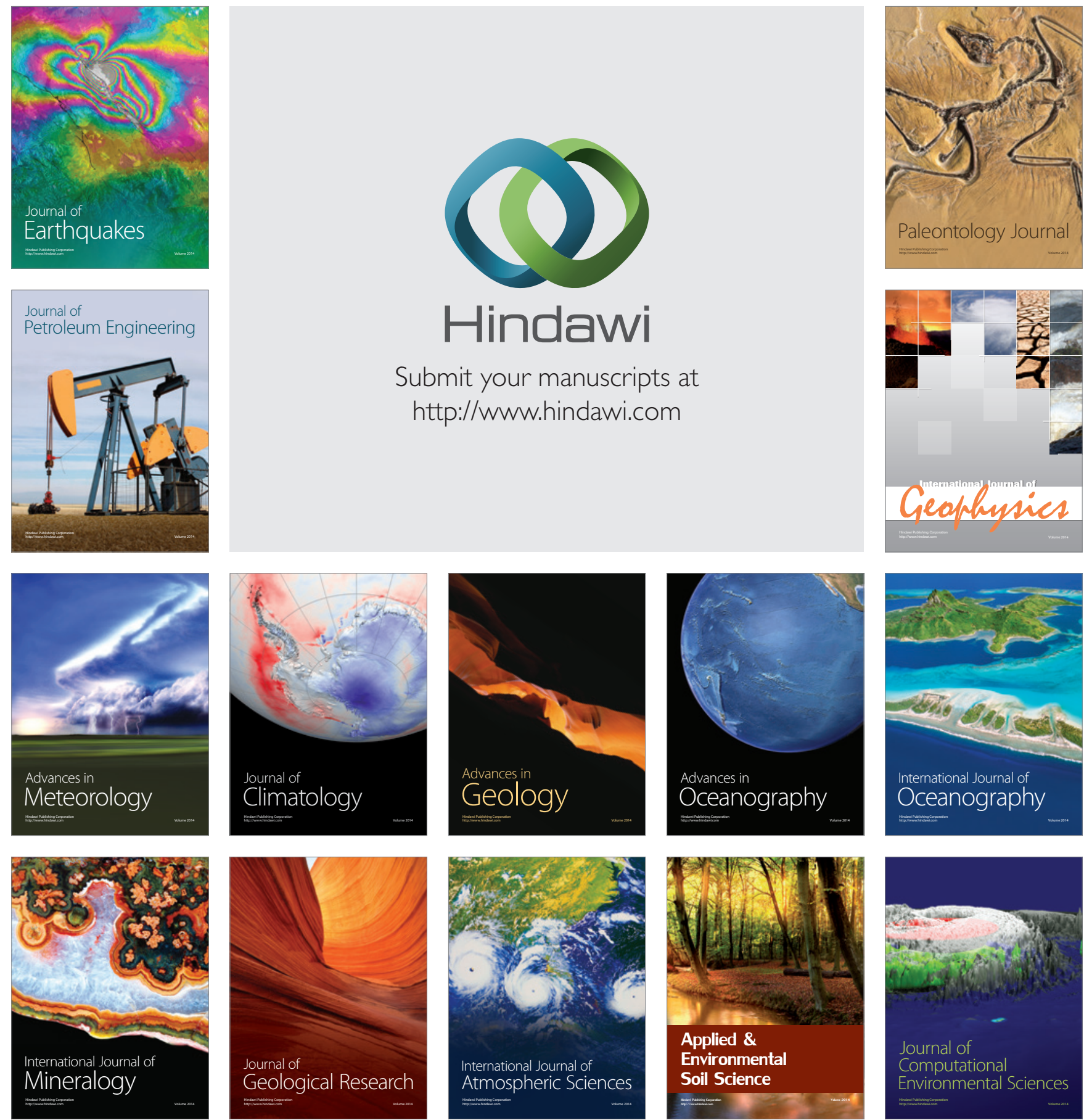